\title{
EFFECTS OF ANTI-ULCER AGENTS ON THERMAL-CORTISONE-INDUCED ULCERS IN RATS
}

\author{
Nobuhiro INATOMI, Yasunobu ISHIHARA and Susumu OKABE \\ Department of Applied Pharmacology, Kyoto College of Pharmacy, \\ Yamashina, Kyoto 607, $\mathbf{J}$ Japan \\ Accepted January 17, 1979
}

Recently, Watanabe \& Kuno (1) and Tsuji (2) devised a new method of producing gastric ulcers by employing thermocautery of the serosal surface of the stomach of mice or rats. With a modification of this method, we administered cortisone after induction of the thermal ulcers. The healing processes of thermal and thermal-cortisone ulcers in rats and curative effects of several drugs on the ulcers are described herein.

\section{Thermal ulcer induction}

In male Sprague-Dawley rats $(250-300 \mathrm{~g})$ under ether anesthesia, laparotomy was performed through a midline incision and the stomach was withdrawn from the abdomen. The head of the thermocautery, $8 \mathrm{~mm}$ in diameter and heated at $70^{\circ} \mathrm{C}$, was then applied to the junctional portion of the antrum and body in the anterior wall for $10 \mathrm{sec}$ with slight pressure from a finger placed behind the stomach. The abdomen was closed and the animals fed the usual laboratory chow diet.

\section{Thermal-cortisone ulcer induction.}

Unlike the case of thermal ulcer, the cauterized area was covered with the greater omentum and fixed with several sutures to prevent adhesion of the ulcerated area to adjacent organs (mainly the liver). The fixation was made at least $0.5 \mathrm{~mm}$ apart from the cauterized area and care was taken not to disturb any blood vessels running through the serosal surface. The abdomen was closed and the animals fed the usual laboratory chow diet. Cortisone acetate (Nippon-Merck-Banyu) $60 \mathrm{mg} / \mathrm{kg}$ was administered i.m. to the rats for 5 consecutive days beginning on the day of induction of the thermal ulcer. Penicillin G potassium (Meiji) $8,000 \mathrm{U} / \mathrm{kg}$ and streptomycin sulfate (Meiji) $40 \mathrm{mg} / \mathrm{kg}$ were also given i.m. to the rats to prevent bacterial infection during cortisone administration. Animals were sacrificed at proper intervals to assess the healing process of thermal or thermal-cortisone ulcers. The stomach was removed, filled with $14 \mathrm{ml}$ of $1 \%$ formalin solution and immersed into $1 \%$ formalin solution for $10 \mathrm{~min}$ to fix the outer and inner layers. The stomach was incised along the greater curvature, spread on a glass pad and the ulcerated area $\left(\mathrm{mm}^{2}\right)$ was measured under the dissecting microscope $(10 \times)$. Test drugs were administered orally to the rats with gastric ulcers, 3 times a day for 12 consecutive days beginning the day after the last administration of cortisone. Drugs used were propantheline bromide (Kongo Kagaku), pirenzepine dihydrochloride (5, 11-dihydro-11-[4-methylpiperazinl-yl) acetyl]-6H-pyrido [2,3b-] [1,4]benzodiazepin-6-on-dihydrochloride: Dr. Karl Thomae), sulpiride (Fujisawa), gefarnate (Sumitomo-Kagaku), and aluminum sucrose sulfate (Chugai). Aluminum sucrose sulfate was dissolved in water and the other drugs were suspended in $1 \%$ 
carboxymethylcellulose (CMC) solution. The dose for each drug was based on our previous experiments (3-5) in which these compounds had an apparent effect on inhibition of acute or chronic ulcers in rats. The control animals were given $1 \% \mathrm{CMC}$ solution 3 times a day. Student's $t$-test was used for statistical analysis.

With thermocautery of the serosal surface of the rat stomach, a clearly defined ulceration was produced on the first day after operation, approximately $20 \mathrm{~mm}^{2}$ in size. As shown in Table 1, the thermal ulcers healed rather rapidly and healing was nearly complete within 27 days. The administration of cortisone for 5 days, however, apparently delayed the healing of thermal ulcers. On the first day after cortisone treatment, the size of ulcers was almost identical to that of the thermally-induced ulcer but the depth was deeper. At 9, 13,17 or 27 days, the ulcer index was significantly different between thermal and thermalcortisone ulcers, i.e., the thermal-cortisone-induced ulcers were not healed, even at 27 days. In contrast to rats with thermal ulcers, the rats on cortisone lost about $40-50 \mathrm{~g}$ by the end of cortisone treatment but gradually gained in weight thereafter. As shown in Table 2, propantheline $(270 \mathrm{mg} / \mathrm{kg} /$ day $)$, pirenzepine $(270 \mathrm{mg} / \mathrm{kg} /$ day $)$ and aluminum sucrose sulfate ( $900 \mathrm{mg} / \mathrm{kg} /$ day) produced a significant acceleration of healing of thermal-cortisone-induced ulcers. Sulpiride $(60 \mathrm{mg} / \mathrm{kg} /$ day $)$ and gefarnate $(150 \mathrm{mg} / \mathrm{kg} / \mathrm{day})$ had no effect on the healing of the ulcers.

The present study confirmed that thermocautery of the serosal surface of the rat stomach readily produced ulcers and healing of these ulcers was rapid. Cortisone is known to

TABLE 1. Healing processes of thermal and thermal-cortisone-induced ulcers in rats

\begin{tabular}{lcccccc}
\hline Ulcer model & \multicolumn{7}{c}{ Days after ulceration } \\
& 1 & 5 & 9 & 13 & 17 & 27 \\
\hline & & \multicolumn{5}{c}{ Ulcer index $\left(\mathrm{mm}^{2}\right)$, mean \pm s.e. } \\
Thermal & $23.3 \pm 1.5$ & $13.9 \pm 1.0$ & $6.1 \pm 0.8$ & $1.8 \pm 0.4$ & $1.2 \pm 0.3$ & $0.6 \pm 0.2$ \\
Thermal-cortisone & $21.2 \pm 1.1$ & $16.9 \pm 1.2$ & $12.6 \pm 0.9^{*}$ & $10.8 \pm 1.4^{*}$ & $5.5 \pm 0.8^{*}$ & $3.8 \pm 0.7^{*}$ \\
\hline
\end{tabular}

Each group included 10 rats. *The mean ulcer index between thermal and thermalcortisone-induced ulcers is statistically different at the level of $\mathrm{p}=0.05$.

TABLE 2. Effects of various compounds on healing of thermal-cortisone-induced ulcers in rats

\begin{tabular}{lccccc}
\hline Treatment & $\begin{array}{c}\text { Dose } \\
(\mathrm{mg} / \mathrm{kg} / \text { day })\end{array}$ & $\begin{array}{c}\text { No. of } \\
\text { rats }\end{array}$ & $\begin{array}{c}\text { Ulcer index } \\
\left(\mathrm{mm}^{2}\right) \\
\text { mean } \pm \text { s.e. }\end{array}$ & $\begin{array}{c}\text { Healing index } \\
(\%)\end{array}$ & $P$ \\
Control & 32 & $3.9 \pm 0.3$ & & \\
Propantheline & $90 \times 3$ & 23 & $2.6 \pm 0.5$ & 33.3 & $<0.05$ \\
Pirenzepine & $90 \times 3$ & 32 & $2.1 \pm 0.3$ & 46.2 & $<0.05$ \\
$\begin{array}{l}\text { Sulpiride } \\
\text { Gefarnate }\end{array}$ & $20 \times 3$ & 20 & $3.7 \pm 0.5$ & 5.1 & N.S. \\
$\begin{array}{l}\text { Aluminum sucrose } \\
\text { sulfate }\end{array}$ & $30 \times 3$ & 20 & $4.2 \pm 0.5$ & -7.7 & N.S. \\
\hline
\end{tabular}

Each drug was given p.o. daily $\times 3$ for 12 consecutive days after the induced ulceration. 
delay healing of chronic type of gastric ulcers in rats (6-8). Umehara et al established a unique method of production of chronic gastric ulcers, i.e., clamping-cortisone ulcers, in rats (7). We have provided evidence herein that cortisone significantly delayed the healing of thermal ulcers resulting in the occurrence of long lasting ulcers. Several drugs now in clinical use significantly accelerated the healing of thermal-cortisone ulcers when given in a continuous administration. This ulcer model, therefore, appears to be useful as a screening test for anti-ulcer drugs. Of these drugs, propantheline and pirenzepine are potent inhibitors of gastric secretion in rats $(9,10)$. In addition, aluminum sucrose sulfate is reportedly a potent antipeptic agent (11). It would appear therefore that gastric secretion of acid and pepsin exerts an unfavorable influence on healing of thermal-cortisone ulcers. In our previous study, we found that pirenzepine apparently accelerated the healing of acetic acid ulcer in rats, whereas propantheline did not (3). While gefarnate and sulpiride had no effect on thermalcortisone ulcers, it has been reported by (S.O.) that gefarnate and sulpiride accelerated the healing of stress ulcers (4) and acetic acid ulcers (5) in rats, respectively. Our data herein suggest that different chronic gastric ulcer models should be employed to accurately screen anti-ulcer drugs for clinical use.

\section{REFERENCES}

1) Watanabe, K. and KUno, H.: Effect of carbenoxolone sodium on the experimental gastric ulcers induced by reserpine or prednisolone in rats and on thermocauterization in mice. Pharmacometrics 11, 239-243 (1976)

2) Tsuj, K.: Pathogenesis of the gastric ulcer induced by the serosa and mucosa searing method. Japan. J. Gastroent. 75, 607-620 (1978)

3) Okabf, S., Nosaka, A., Matsumoto, M. and Kawahara, Y.: Effects of pirenzepine, propantheline bromide or ulcerlmin on experimental peptic ulcers in rats. Pharmacometrics 15, 1235-1240 (1978)

4) TAKAGI, K. AND OKABE, S.: The effects of drugs on the production and recovery processes of the stress ulcer. Japan. J. Pharmacol. 18, 9-18 (1968)

5) OKabe, S., SAZiKI, R. AND TAKagi, K.: Effects of sulpiride on the production and healing of experimental gastric ulcers. Pharmacometrics 3, 301-304 (1969)

6) Skoryna, S.C., Webster, D.R. ANd Kahn, D.S.: A new method of production of experimental gastric ulcer; the effects of hormonal factors on healing. Gastroenterology 34, $1-10(1958)$

7) Umehara, S., Ito, H., Tabayashi, T., Hayashi, T., IshiI, A., Kawasaki, H., Imai, K. and HORl, H.: Studies on an experimental chronic gastric ulcer induced by the clampingcortisone methods in rats. Peptic Ulcer, p. 118-137, Lippincott, Philadelphia (1971)

8) OKabe, S., SAZiki, R. AND TAKAGI, K.: Cortisone acetate and stress on the healing process of chronic gastric ulcer in rats. J. appl. Physiol. 30, 793-796 (1971)

9) KoWALEWSKI, K.: Effect of long term treatment with an anticholinergic drug on gastric secretion in rats. Am. J. dig. Dis. 12, 988-993 (1967)

10) Leitold, M. ANd Engelhorn, R.: Pharmakologische Prüfung der magense-kretionshemmenden Wirkung von 5, 11-Dihydro-11-[(4-methyl-piperazin-1-yl)acetyl]-6H-pyrido [2,3-b] [1,4] benzodiazepin-6-on-dihydrochloride (LS 519). Therapiewoche, 27, 1517$1531(1977)$

11) Miyoshi, A., Moriga, M., Kobayashi, M., Suyama, T., Kiguchi, Y. and Kishimoto, S.: Experimental and clinical studies on anti-pepsin preparations. 1. Anti-pepsin and anti-ulcerogenic activities of sucrose sulfate ester. Japan. Arch. Int. Med. 15, 419-425 (1968) 